\title{
SOME INTERESTING GASTEROMYCETES (BASIDIOMYCOTA) IN DRY AREAS FROM NORTHEASTERN BRAZIL
}

\author{
Iuri Goulart Baseia ${ }^{1}$ \\ Tereza Cristina de O. Galvão ${ }^{2}$
}

Recebido em 20/07/00. Aceito em 02/05/01.

\begin{abstract}
RESUMO - (Alguns Gasteromycetes (Basidiomycota) interessantes em áreas secas do nordeste brasileiro). Diversos gasteromicetos xerófilos em vegetação de caatinga pertencentes a quatro espécies foram identificados: Astraeus hygrometricus (Pers.: Pers.) Morg., Myriostoma coliforme (With.: Pers.) Corda, Podaxis pistillaris (L.: Pers.) Fr. emend. Morse and Tulostoma exasperatum Mont. Com exceção P. pistillaris, as demais espécies representam primeiros registros para regiões de caatinga. São fornecidas descrições das características macro e microscópicas, incluindo considerações taxonômicas e ecológicas.
\end{abstract}

Palavras-chave - taxonomia, fungos xerófilos, caatinga

\begin{abstract}
Some interesting Gasteromycetes (Basidiomycota) in dry areas from northeastern Brazil). Some xerophyles gasteroid fungi from 'caatinga' vegetation are joined here. Several specimens belonging to four species were identified: Astraeus hygrometricus (Pers.: Pers.) Morg., Myriostoma coliforme (With.: Pers.) Corda, Podaxis pistillaris (L.: Pers.) Fr. emend. Morse and Tulostoma exasperatum Mont. All of these species, except $P$. pistillaris, represent first records from the caatinga region. Descriptions of macro and microscopic features are given including taxonomic and ecological considerations.
\end{abstract}

Key words - taxonomy, xerophilic fungi, caatinga

\section{Introduction}

The gasteroid mycota from dry areas of northeastern Brazil has received sporadic attention from collectors in the past and has not been adequately collected, few species in the scattered herbaria have been insufficiently reported. This paper highlights a few of the more unusual gasteroid fungi collected in some areas of the caatinga region .
The vegetation of the drier part of northeastern Brazil was called caatinga by the natives of that region, this name being maintained both in common use and scientific literature. According to Andrade-Lima (1981), although it is not the only climate type peculiar to the region, it is nevertheless the climate responsible for the caatinga vegetation.

Low and irregular rainfall and high temperatures are the main reasons for such climate.

\footnotetext{
${ }_{1}^{1}$ Aluno de Doutorado do Instituto de Biociências (USP), Bolsista CAPES. Instituto de Botânica, C. Postal 4005, 01061970, São Paulo, Sp, Brasil. E-mail: ibaseia@bol.com.br

${ }^{2}$ Mestre em Ciências Biológicas. E-mail: t_galvao@uol.com.br
} 
Floristically this biome is not a completely isolated vegetation type, with several species with widespread distribution in another biomes.

\section{Material and methods}

Collections of Gasteromycetes species basidiomata were made on March/1997 to June/ 1998, in areas of caatinga region from States of Paraíba and Pernambuco.

Climatic conditions are of the BSh type according to Köppen System. Fresh and dried material were prepared for examination in light microscopy by removing small sections of the peridium and gleba from the basidiomata and soaking them in Melzer's reagent and 5\% $\mathrm{KOH}$ (Singer, 1986). Colour terms in parenthesis are those of Kornerup \& Wanscher (1978), abbreviated as $\mathrm{KW}$.

The material is preserved at the Herbarium of the Instituto de Botânica, Seção de Micologia e Liquenologia (SP), abbreviated by acronyms according to the Index Herbariorum (Holmgren et al., 1990).

\section{Results}

\section{SCLERODERMATALES: ASTRAEACEAE}

Astraeus hygrometricus (Pers.: Pers.) Morg., J. Cinc. Soc. Nat. Hist. 12: 20, f. 12, 1889.

Basonym: Geastrum hygrometricum Pers., Syn. Meth. Fung. 135, 1801. Fig. 1-3

Unexpanded basidiomata subglobose, 20$25 \mathrm{~mm}$ diam., epigeous. Exoperidium dehiscent to 8-14 lobes at maturity, reddish blond (KW$5 \mathrm{C} 4$ ) to yellowish brown (KW-5E5), thick, hard, four-layered: mycelial layer hyphae 4-6 $\mu \mathrm{m}$ diam., branched; fibrous layer hyphae 6-8 $\mu \mathrm{m}$ diam., branched; collenchyma-type layer hyphae 3-4 $\mu \mathrm{m}$ diam, branched; soft layer hyphae 3-6 $\mu \mathrm{m}$ diam. Endoperidium reddish blond (KW-5C3), thin, membranous, oblate, no middle columela inside, hyphae 4-5 $\mu \mathrm{m}$ diam., branched; ostiole smooth to lacerate present. Gleba dark grey (KW-3F1), capillitium hyphae almost hyaline, asseptate, branched, 4-6 $\mu \mathrm{m}$ in diam.; basidiospores verrucose, brown, globose to subglobose, $7-10 \mu \mathrm{m}$ diam.

Material examined: BRAZIL, Paraíba: $\mathrm{Mu}-$ nicípio de Patos, 03/VI/1997, I. G. Baseia 180 (SP 307514); Pernambuco: Município de Afrânio, 08/IV/1998, I. G. Baseia 267 (SP 307515).

Additional material examined: (donated to SP Herbarium): USA, New York: Hampton Beach, 27/VI/1959, det. C. Rogerson (SP 141509); PAKISTAN: $12 /$ VIII/1962, det. S. Ahmad (SP 107394).

Habitat: In groups on sandy soil at the base of 'espinheiro' (Chloroleucon foliolosum (Benth.) G. P. Lewis, Mimosaceae), in dry area.

Distribution: Argentina (Nouhra and Dominguez de Toledo, 1998), Brazil (Rick, 1961), China (Liu, 1984), France (Demoulin, 1983), Germany (Zeller, 1948), Mexico (Esqueda-Valle et al., 1990), Spain (Calonge and Demoulin, 1975), United States of America (Coker and Couch, 1928; Long and Stouffer, 1948).

Remarks: The genus Astraeus was proposed by Morgan (1889) whilst transferring Geastrum hygrometricus Pers. According to Nouhra and Dominguez de Toledo (1998), two species are currently included, A. hygrometricus (Pers.) Morgan and A. pteridis (Shear) Zeller. The genus was monotypic until Shear (1902) described Scleroderma pteridis as a new species, being subsequently transferred to Astraeus, by Zeller (1948).

This transfer and also its placement in the family Astraeaceae V. J. Stanek (order Sclerodermatales) seems to be generally accepted (Dring, 1973; Calonge and Demoulin, 1975; Demoulin and Marriott, 1981; Sunhede, 1989; Mornard, 1993).

According to Coetzee et al. (1997), the correct name and author citation are Astraeus hygrometricus (Pers.: Pers.) Morgan, whereas in the 

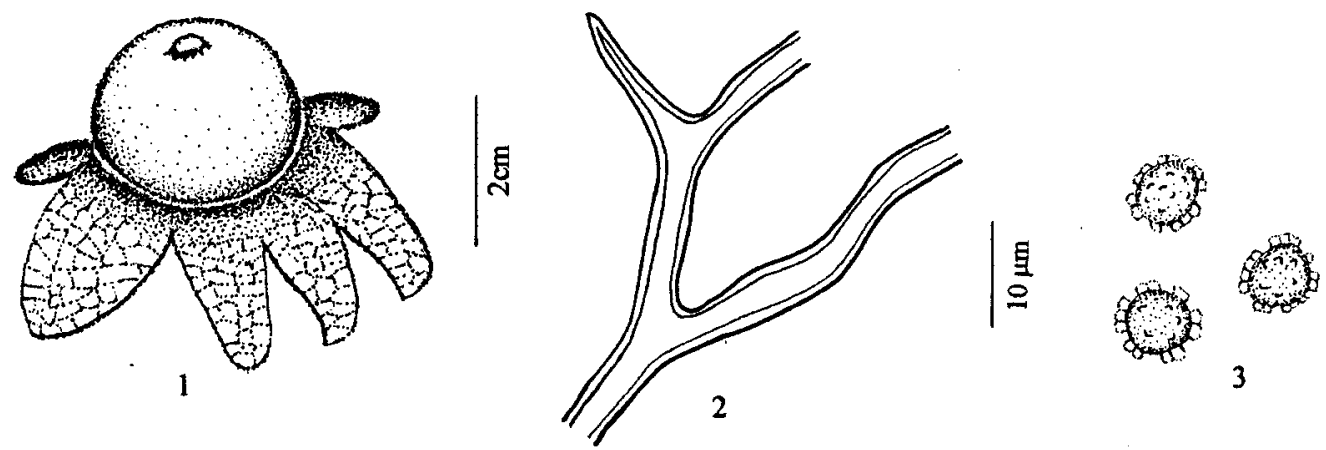

Figure 1-3. Astraeus hygrometricus (Pers.: Pers.) Morg. 1. basidioma (general aspect); 2. capillitium hyphae;

3. basidiospores.

Zeller (1948) opinion this species is cosmopolitan throughout temperate climates.

Coker and Couch (1928) stated A. hygrometricus to be a "worldwide in distribution" although it had not been satisfactorily recorded from South America, in spite of several mycological explorations. A. hygrometricus was cited from Brazil by Rick (1961) from Rio Grande do Sul, constituting the first register from the northeastern Brazil.

\section{LYCOPERDALES: GEASTRACEAE}

Myriostoma coliforme (With.: Pers.) Corda, Anleit. zum Stud. der Myc. 16-17, 1842.

Basonym: Geastrum coliforme Pers., Syn. Meth. Fung. 131, 1801. Fig. 4-6. Unexpanded basidiomata subglobose, 30-50 mm diam., epigeous. Exoperidium dehiscent to 6-7 rays at maturity, reddish blond (KW-5C4), revolute, rigid, not hygroscopic, two-layered; mycelial layer glabrous, smooth, hyphae 4.7-7 $\mu \mathrm{m}$ diam., thickwalled, finely spinose; soft layer yellowish white (KW-4A3) to yellowish brown (KW-5F4), adnate, rigid at first, later peeling off. Endoperidium 20-30 mm diam., brownish grey (KW-5D2), pluripedicellate (6-8), pluriostiollate (6-8), subglobose, hyphae 4-5 $\mu \mathrm{m}$ diam., branched; mouths fibrillose, peristome absent. Gleba yellowish brown (KW-5D5), pulverulent, several columellas (6-8); capillitium hyphae pale brown, unbranched, 4-4,5 $\mu \mathrm{m}$ diam., thickwalled; basidiospores globose, with halo, 3.5$4.5 \mu \mathrm{m}$ diam. exclusive of halo, 6-7 $\mu \mathrm{m}$ diam. including halo, strongly warted, pale brown.

Material examined: BRAZIL, Paraíba: Município de Patos, 03/VI/1997, I. G. Baseia 183 (SP 307514); Pernambuco: Município de Ouricuri, 15/VII/1997 , I. G. Baseia 197 (SP 307515).

Additional material examined: (donated to SP Herbarium): BRAZIL, Rio Grande do Sul: Parecí, 1918, Rick, J. (SP 33983); Santa Catarina: Município de Blumenau, 17/VIII/1965, Lowy 212-B (SP 92452).

Habitat: Solitary on sandy soil near at 'umbuzeiro' (Spondias tuberosa Arruda Cam., Anacardiaceae), in dry place .

Distribution: Argentina (Spegazzini, 1927), Brazil (Rick, 1961), Canary Islands (Beltrán-Tejera et al., 1998), Hawaii (Smith and Ponce de Leon, 1982), Mexico (Pardavé, 1991), South Africa (Bottomley, 1948), United States of America (Coker and Couch, 1928; Long and Stouffer, 1948).

Remarks: The genus Myriostoma only contains one species: $M$. coliforme, characterized by an endoperidium borne on many pedicels and by many ostioles. It was originally described from England by Persoon (1801). Controversy about 

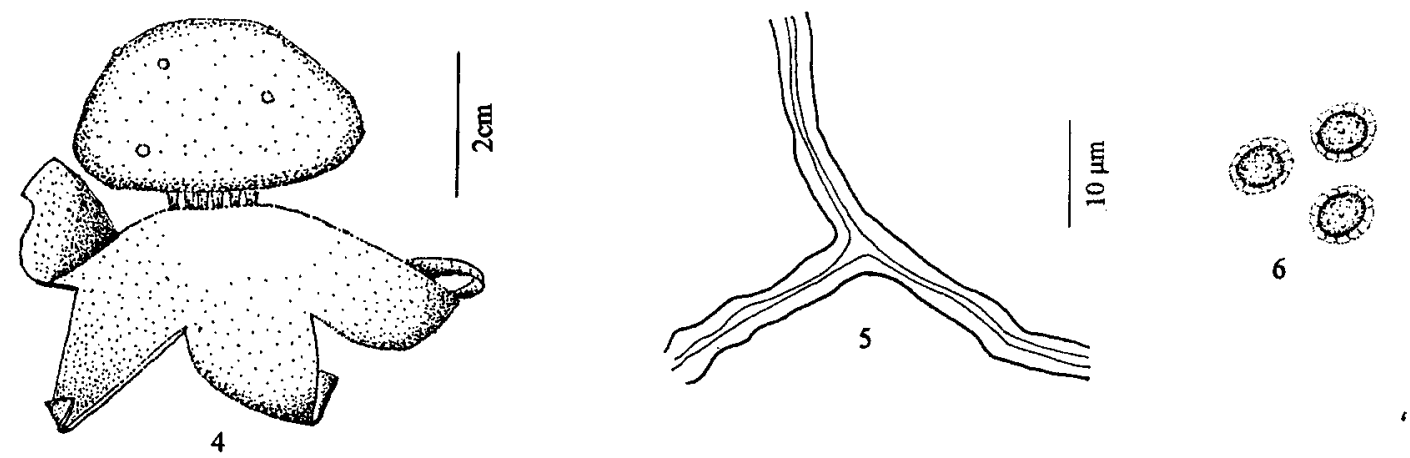

Figure 4-6. Myriostoma coliforme (With.: Pers.) Corda. 4. basidioma (general aspect); 5. capillitium hyphae; 6. basidiospores.

the taxonomic position of the genus Myriosto$m a$ exists. In spite of the greater number of recent authors (Sunhede, 1989; Mornand, 1993; Hawksworth et al. 1995; Coetzee et al. 1997 and Beltrán-Tejera et al. 1998) they employed the genus Myriostoma in the family Geastraceae (Lycoperdales); some others (Dring, 1973 and Ponce de Leon, 1982) have transferred this taxon to the family Astraeaceae (Sclerodermatales) based on the lacunar development of the gleba, according to them, probably in analogy with Astraeus. According to Coetzee et al. (1997), the correct citation to this species should be Myriostoma coliforme (With.: Pers.) Corda. At the present time, only one report of Geastraceae species from northeastern Brazil, appears in the literature (Kimbrough et al., 1995) to State of Pernambuco. M. coliforme was cited for the first time from Brazil by Rick (1961) to State of Rio Grande do Sul. This is the first report from the caatinga region.

\section{PODAXALES: PODAXACEAE}

Podaxis pistillaris (L.: Pers.) Fr. emend. Morse, Micologia 25: 27, 1933.

Basonym: Scleroderma pistillare (L.) Pers., Syn. Meth. Fung. 150, 1801. Fig. 7-9. Basidiomata epigeous, stipitate, $12-17 \mathrm{~cm}$ high, consisting of an campanuliform to subcylin- drical sporocarp supported on a hard subcylindrical stipe. Peridium three-layered, squamous surface yellowish white (KW-4A1), dehiscing by splitting upward from the point of attachment to the stipe, resulting in 2-4 rays bending upward, deciduous, outer hyphae $7-$ $8 \mu \mathrm{m}$ diam.; columella percurrent, tapering gradually upwards.

Gleba dark grey (KW-3F3) to black, pulverulent; capillitium hyphae 6-8 $\mu \mathrm{m}$ diam., thin-walled, almost hyaline, branched; basidiospores subglobose to ellipsoid, pale brown, 10-13 x 8-10 $\mu$ m diam., thick-walled, smooth with well-marked germ pore.

Material examined: BRAZIL, Paraíba: Município de Cajazeiras, 24/V/1997, I. G. Baseia 173 (SP 307511).

Additional material examined: (donated to SP Herbarium): BRAZIL, São Paulo: São José dos Campos - cerrado region, 30/V/1962, det. C. Rogerson (SP 98313).

Habitat: In groups on sandy soil at the base of 'maniçoba' (Manihot pseudoglaziovii Pax. et $\mathrm{K}$. Hoffman), in dry area after first rains.

Distribution: Afghanistan (Watling and Gregory, 1977), Argentina (Martínez, 1971), Australia (Hilton and Kenneally, 1981), Congo (Dissing and Lange, 1962), Iran (Watling and Gregory, 1977), Israel (Dring and Rayss, 1963; Binyamini, 1973), South Africa (Bottomley, 1948) United States of 


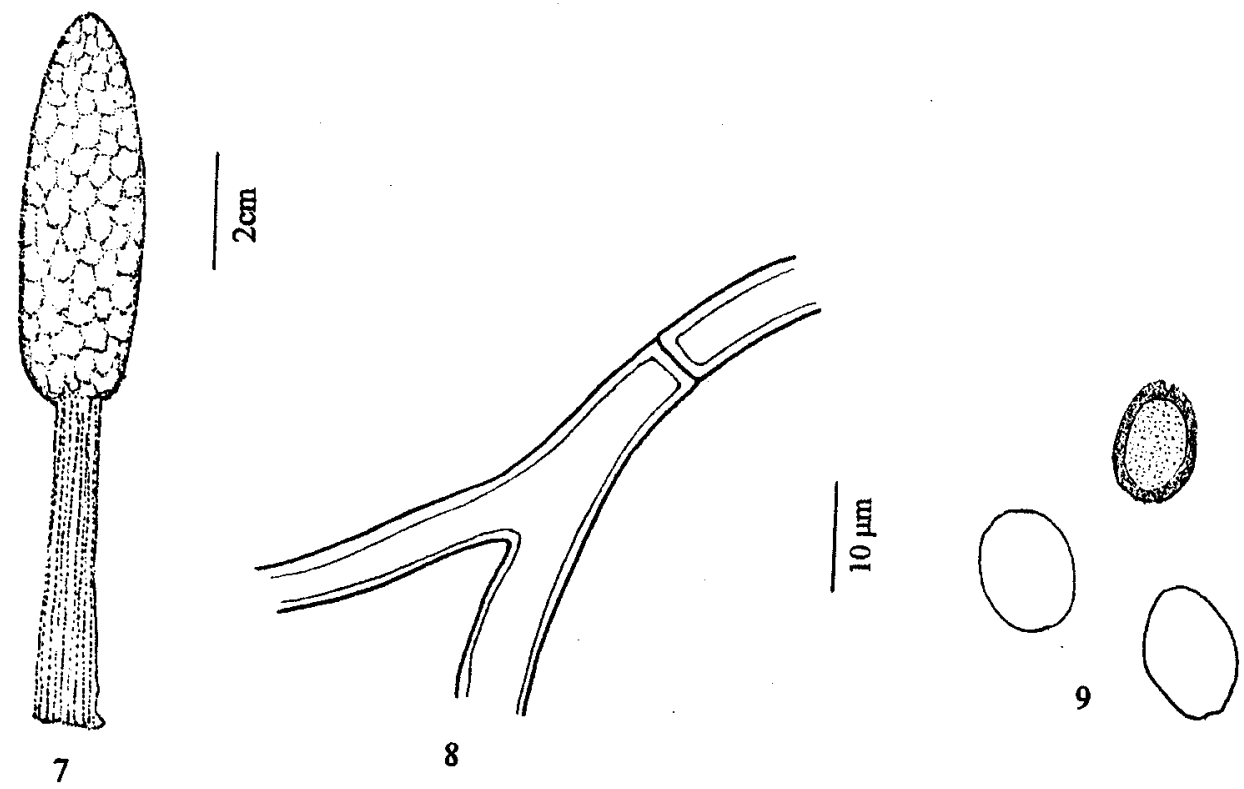

Figure 7-9. Podaxis pistillaris (L.: Pers.) Fr. emend. Morse. 7. basidioma (general aspect); 8. capillitium hyphae; 9. basidiospores.

America (Brasfielf, 1937), West Tropical Africa (Dring, 1964).

Remarks: According to several authors (Morse, 1933; McKnight and Stransky, 1980; DeVilliers et al., 1989) $P$. pistillaris is a rather polymorphic species with great variation in the size of the basidiomata, basidiospores and structure of the capillitium hyphae. Chaves Batista (1950) without comparing or discussing any species previously reported, described three new species of Podaxis from Brazil using a combination of microscopic basidiospore characteristics. However, these features in our opinion, are not a solid support to establish these new taxa and probably are not valid, since there were included in concept of $P$. pistillaris sensu Morse.

According to Coetzee et al. (1997) the terms of article 47.1 of the Tokyo Code, the reassessment of this species by Morse (1933) “... does not warrant a change of authorship of this taxon", as has been done by Bottomley (1948). The appropriate citation, as employed in Dring and Rayss
(1963), Binyamini (1973) and De Villiers et al. (1989), adopted here to reflect the changes to the ICBN enacted in 1981 (Korf, 1983), is Podaxis pistillaris (L.: Pers.) Fr. emend. Morse.

\section{TULOSTOMALALES:}

\section{TULOSTOMATACEAE}

Tulostoma exasperatum Mont., Ann. Sci. Nat. (Bot.) II, 8: 362, 1837. Fig. 10-12. Basidiomata composed of sporocarp and stipe. Sporocarp depressed globose, 12-16 mm high, 14-22 mm wide; exoperidium composed by long pointed, conical warts, 1-2 mm long, dark brown (KW5F3), deciduous on upper part leaving distinct yellowish white (KW-4A2) scars. Stipe woody, yellowish brown (KW-5F2), cylindrical, $3-5 \mathrm{~cm}$. tall. Endoperidium almost yellowish white (KW-4A1), composed of hyphae similar to the capillitium threads, but hyaline; mouth raised, fibrillose, about $1 \mathrm{~mm}$ diam. Gleba dark brown (KW-5F4), pulverulent; capillitium hyphae thin- 


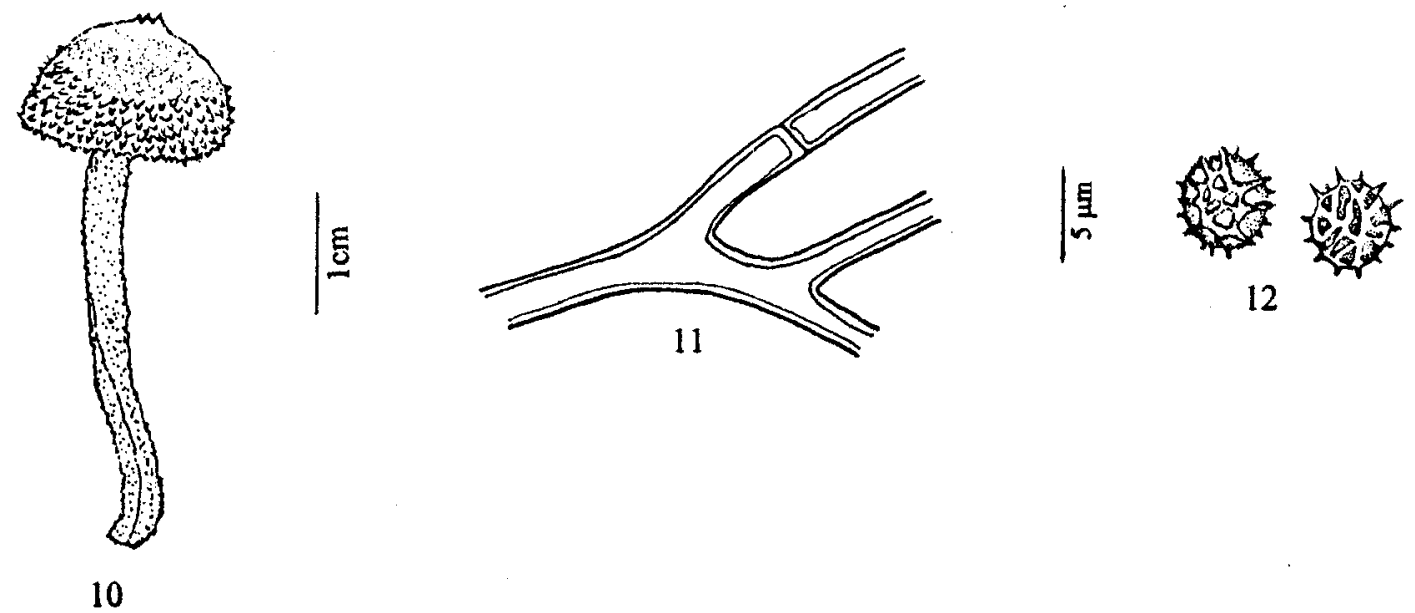

Figure 10-12. Tulostoma exasperatum Mont. 10. basidioma (general aspect); 11. capillitium hyphae; 12. basidiospores.

walled, branched, not exceeding diameter of basidiospores, hyaline, rarely septate with unswollen nodes, 1.5-3 $\mu \mathrm{m}$ diam.; basidiospores globose to subglobose, 6-7 $\mu \mathrm{m}$ diam., very strongly warted, pale brown.

Material examined: BRAZIL, Paraíba: Município de Cajazeiras, 25/V/1997, I. G. Baseia 204 (SP 307510); Pernambuco: Município de Arcoverde, 01/VIII/1997, I. G. Baseia 217 (SP 307509).

Additional material examined: (donated to SP Herbarium): BRAZIL, São Paulo: $\mathrm{Mu}-$ nicípio de São Paulo, Parque do Estado, 18/ II/1920, det. K. Fidalgo, rev. D. M. Dring (SP 98313).

Habitat: In groups on decaying wood of 'jurema-preta' (Mimosa tenuiflora (Willd.) Poiret., Mimosaceae), in dry place.

Distributio: Argentina (Spegazzini, 1927), Brazil (Lloyd, 1906; Rick, 1961; Bononi et al. 1984), Cuba (Saccardo, 1888; White, 1901), India (Long and Ahmad, 1947), Philippine Islands and United States of America (Long, 1947), Venezuela (Dennis, 1970). Remarks: The genus Tulostoma was proposed by Persoon (1801) and it is charac- terized by stipe inserted in a socket at the base of the subglobose endoperidium which opens by a small apical mouth. Only one other genus, named Schizostoma has a stipe of this nature.

From Schizostoma however, Tulostoma differs in having a well-developed mouth and septate capillitium threads. According to Wright (1987) this group is worldwide in distribution with a presence to warm and sandy places. Currently, 79 species are considered (Hawksworth et al., 1995).

All of the Tulostoma species occurring on the ground, with the exception of two or three species which grow on decaying wood, like as $T$. exasperatum, characterized by exoperidium covered by long pointed conical warts, shape of basidiospores very strongly warted.

\section{Acknowledgments}

We acknowledge the financial support from the Coordenação de Aperfeiçoamento de Pessoal de Ensino Superior (CAPES) and the Instituto de Botânica (IBt) for the support and laboratory facilities. 


\section{References}

Andrade-Lima, D. 1981. The caatingas dominium. Rev. Bras. Bot. 4: 149-153.

Binyamini, N. 1973. Gasteromycetes of Sinai desert. Isr. J. Bot. 22: 33-37.

Beltrán-Tejera, E.; Bañares-Baudet, A. and RodriguezArmas, J. L. 1998. Gasteromycetes of the Canary islands. Some noteworthy new records. Mycotaxon 67: 439-453.

Bononi, V. L.; Guzmán, G. and Capelari, M. 1984. Basidiomycetos do Parque Estadual da Ilha do Cardoso. V: Gasteromycetos. Rickia 11: 91-97.

Bottomley, A. M. 1948. Gasteromycetes of South Africa. Bothalia 4: 473-810.

Brasfield, T. W. 1937. The morphology of Podaxis pistillaris. Univ. Iowa Stud. Nat. Hist. 17: 100-121.

Calonge, F. D. and Demoulin, V. 1975. Les Gastéromycètes d'Espagne. Bull. Soc. Mycol. France 91(2): 247-292.

Chaves Batista, A. 1950. Três novos Podaxis de Pernambuco. Bol. Secr. Agric. Recife 17: 320-324.

Coetzee, J. C.; Eicker, A. and Van Wyk, A. E. 1997. Taxonomic notes on the Geastraceae, Tulostomataceae, Nidulariaceae and Sphaerobolaceae (Gasteromycetes) sensu Bottomley, in southern Africa. Bothalia 27 (2): 117-123.

Coker, W. C. and Couch, J. N. 1928. The Gasteromycetes of Eastern United States and Canada. Chapel Hill, p. 201.

Demoulin, V. 1983. Un site remarquable pour ses Gastéromycètes: Les grès rouges permiens du nord du massif des Maures (var. France). Cryptog. Mycol. 4: 9-18.

Demoulin, V. and Marriott, J. V. R. 1981. Key to the Gasteromycetes of Great Britain. Bulletin 15: 3756.

DeVilliers, J. J. R. 1994. A reassessment of the southern African Geastraceae using morphological features. Ph.D. Thesis, University of Pretoria.

DeVilliers, J. J. R.; Eicker, A. and Westhuizen, G. C. A. 1989. A new section and two new species of Podaxis (Gasteromycetes) from South Africa. S. Afr. J. Bot. 55(2): 159-164.

Dennis, R. W. G. 1970. Fungus flora of Venezuela and adjacents countries. Lehre: J. Cramer - p. 531.

Dissing, H. and Lange, M. 1962. Gasteromycetes of Congo. Bull. Jard. Bot. L'etat 32 (4): 325-416.

Dring, D. M. 1964. Gasteromycetes of West Tropical Africa. Mycological Papers 98:1-60.

Dring, D. M. 1973. In: G. C. Ainsworth et al. - The fungi Vol. 4B- Chapter 24, Gasteromycetes.

Dring, D. M. and Rayss, T. 1963. The Gasteromycete fungi of Israel. Isr. J. Bot. 12: 147-178.

Esqueda-Valle, M.; Quintero-Ruiz, T.; Pérez-Silva, E. and Aparicio-Navarro, A. 1990. New reports of Gasteromycetes from Sonora. Rev. Mex. Micol. 6: 91 104.

Hawksworth, D. L.; Kirk, P. M.; Sutton, B. C. and Pegler, D. N. 1995. Dictionary of the fungi. Survey, 8 ed., International Mycological Institute, p. 412.

Hilton, R. N. and Kenneally, K. F. 1981. The desert Coprinus fungus Podaxis pistillaris in Western Australia. West. Aust. Nat. 15: 21-26.

Holmgren, P. K.; Holmgren, N. H. and Barnett, L. C. 1990. Index Herbariorum, part I, the Herbaria of the world, $8^{\text {th }}$ edn. Reg. Veg., New York Botanical Garden, New York.

Kimbrough, J. W.; Alves, M. H. and Maia, L. C. 1995. Basidiomycetes saprófitos presentes em troncos vivos e em folhedos de sombreiro (Clitoria fairchiana (Benth.) Howard). Biologica Brasílica 6 (1/2): 51 56.

Korf, R. P. 1983. Sanctioned epithets, sanctioned names and cardinal principles in ':Pers.' and ':Fr.' citations. Mycotaxon 16: 341-352.

Kornerup, A. and Wanscher, J. E. 1978. Methuen Handbook of Colour, $3^{\text {th }}$ edn., Methuen, London.

Liu, B. 1984. The Gasteromycetes of China. Beiheftezur, Nova Hedwigia 74: 1-235.

Lloyd, C. G. 1906. Tylostomae. Myc. Writ. 2: 9-28.

Long, W. H. 1947. Studies in the Gasteromycetes: XV. Notes on new or rare species of Tylostoma. Lloydia 10: $115-135$.

Long, W. H. and Ahmad, S. 1947. The genus Tylostoma in India. Farlowia 3: 225-267.

Long, W. H. and Stouffer, D. J. 1948. Studies in the Gasteromycetes: XVI. The Geastraceae of the SouthWestern United States. Mycologia 40: 547-585.

Martínez, A. 1971. Notes sobre el genero Podaxis (Gasteromycetes) en Argentina. Bol Soc. Argent. Bot. 14: 73-87.

McKnight, K. H. and Stransky, M. 1980. Notes on Podaxis argentinum from North America. Mycologia 72: $195-199$.

Morgan, A. P. 1889. Gastromycetes. Journ. Cin. Soc. Nat. Hist. 11: 141.

Mornard, J. 1993. Contribution à La connaissance des champignons de Maine-et-Loire. 2-Gastéromycètes. Bull. Soc. Mycol. Franc. 109 (3): 149-163.

Morse, E. E. 1933. A study of the genus Podaxis. Mycologia 25: 1-33. 
Nouhra, E. R. and Dominguez de Toledo, L. 1998. The First Record of Astraeus hygrometricus from Argentina. Mycologist 12 (3): 112-113.

Pardavé, L. M. 1991. Gasteromycetes of the State of Agualientes. Rev. Mex. Mic. 7: 71-78.

Persoon, D. C. 1801. Synopsis Methodica Fungorum. Gotinga, p. 708.

Ponce de Leon, P. 1982. Gasteromycetes in: MacGrawHill - Synopsis and Classification of Living Organisms - p. 262.

Rick, J. 1961. Basidiomycetes Eubasidii no Rio Grande do Sul. Brasília. Iheringia 9: 451-480.

Saccardo,P. A. 1888. Sylloge Fungorum 7, Ann Arbor: V.W. Edwards (reprinted, 1944) p. 882.

Shear, C. L. 1902. Mycological notes and new species. Bull. Torrey Bot. Club 29: 451.

Singer R. 1986. The Agaricales in Modern Taxonomy. $4^{\text {th }}$ Edn. Koeltz Scientific Books, Koenigstein.
Smith, C. W. and Ponce de Leon, P. 1982. Hawaiian geastroid fungi. Mycologia 74: 712-717.

Spegazzini, C. 1927. Gasteromycetas Argentinas. Soc. Arg. Cienc. Nat. 8: 421-437.

Sunhede, S. 1989. Geastrae (Basidiomycotina). Morphology, ecology and systematics with special emphasis on the North European species. (Sinopsis Fungorum 1). Fungiflora, Oslo.

Watling, R. and Gregory, N. M. 1977. Larger fungi from Turkey, Iran and neighboring countries. Karstenia 17: 70 .

White, V. S. 1901. The Tylostomaceae of North America. Bull. Torr. Bot. Club 28: 421-436.

Wright, J. E. 1987. The genus Tulostoma (Gasteromycetes). A world monograph. J. Cramer. Berlin, Stuttgart. p. 338.

Zeller, S. M. 1948. Notes on certain Gasteromycetes, including two new orders. Mycologia 40: 639-668. 